It was also the seeds of feminism. The empowerment of a feminist voice, a feminist perspective. The Joyce that planted these seeds is the one I will always remember and honor. I hope I can be forgiven for my apparent insensitivity to another Joyce, one that I now know must have been much more vulnerable than I would/could allow. I continued to argue and debate with her and to be challenged by her insights and ideas. A vibrant, generous, wonderfully alive being, Joyce remains a true inspiration, a personal hero.

John Orbell. Joyce was an intellectual "older sister" for me. As such, she was a guaranteed source of good humored and informed, but unrelenting criticism of my own efforts to make scholarly sense out of the world. There was no way I could escape. Her wit and intelligence, and-with her husband Bill-the effervescent social context she provided for me as for many in the University community (the closest to a salon I have ever known) were magnetic. Still more compelling was the complement she paid me of taking my ideas seriously. I did not fully realize, in my first few years at the University, that Joyce was a rarity in the academic world who took everyone's ideas seriously; but no matter. I could not brush her theoretical, methodological and substantive criticisms off as, somehow, the product of a too-competitive academic context; it was impossible for me not to change my own thinking in response.

Beyond that, through her activist involvement with the profession of Political Science, she reinforced and elaborated my own appreciation that how academic pursuits are organized and conducted matters - matters because power relationships within a profession influence both the careers and the ideas that survive. I came to appreciate that Joyce's intellectual courage in adopting non-conformist and often unpopular (but, in retrospect, prescient) intellectual perspectives was the flip side of her courage as an activist on behalf of women and minorities in the discipline (no less prescient, as it turns out). The complementarity between these two parts of her life was not always straightforward: The intellectual perspective she adopted was occasionally unpopular among her political allies, just as her political perspective was occasionally -sometimes more than occasionally-unpopular among her intellectual allies.

The demands of her struggle with her own health, eventually and tragically, diverted her own extraordinary intellectual and political energies. The impact she had on her friends, on the University of Oregon, and on Political Science-as a scholarly discipline and as a political organization-will, nevertheless, remain.

\section{Fauneil J. Rinn}

Fauneil Rinn, a member of the political science department at San Jose State University since 1960, died from cancer on November 24, 1995. She was sixty-nine.

Fanny was trained in three fields: English (B.A., University of Cincinnati, 1956), journalism (M.S., Columbia University, 1947), and political science (M.A. and Ph.D., University of Chicago, 1954 and
1960). Throughout her professional career, her interests remained eclectic. At San Jose State, in addition to teaching courses in American politics and public administration, she experimented with seminars on Shakespeare's politics, the political novel, and politics and drama. She assumed leadership in a series of inter-disciplinary programs--"Tutorials," "New College," American Studies, Women's Studies, and Gerontology. She played a major role in revising general education requirements, edited a campus-based journal, and served on countless timeconsuming committees.

Beyond the campus, she was a founding member of California Women in Higher Education, the Santa Clara County Caucus of the National Women's Political Caucus, Bay Area Women in Political Science, and the National Women's Studies Association. She did research on Presidential press conferences at the Brookings Institution, was a fellow at the Pacific School of Religion, and regularly attended summer sessions of St. John's College's Graduate Institute in Liberal Education at Santa Fe.

Aside from these institutional connections and contributions, she was known and valued for her encouragement and assistance to students, colleagues, and friends. The memorial service held on December 9 , 1995, gave many of us who loved her an opportunity to pay tribute to her kindness, generosity, and sense of humor. We continue to miss her.

Lela Garner Noble San Jose State University 